\title{
Pyrrolidine-5,5-trans-lactams. 4. Incorporation of a P3/P4 Urea Leads to Potent Intracellular Inhibitors of Hepatitis C Virus NS3/4A Protease
}

\author{
Martin J. Slater*, Elizabeth M. Amphlett, David M. Andrews, Paul Bamborough, \\ Seb J. Carey, Martin R. Johnson, Paul S. Jones, Gail Mills, Nigel R. Parry, \\ Donald O'N Somers, Alan J. Stewart and Tadeusz Skarzynski
}

GlaxoSmithKline Medicines Research Centre, Gunnels Wood Road, Stevenage, SG1 2NY, UK. martin.j.slater@gsk.com

\section{Supporting Information}

\begin{tabular}{llll} 
& & & \\
\cline { 3 - 3 } DCM & Dichloromethane & $\% \mathrm{Th}$. & Percent of theoretical yield \\
CBZ & Benzyloxycarbonyl & $\mathrm{SPE}$ & Solid phase extraction \\
DMSO & Dimethyl sulphoxide & $\mathrm{SiO}_{2}$ & Silica \\
THF & Tetrahydrofuran & $\mathrm{h}$ & Hours \\
BOC & tert-butyloxycarbonyl & Min & Minutes \\
TLC & Thin layer chomatography & Quant & Quantitative \\
Equiv. & Equivalents & & \\
HATU & O-(7-azabenzotriazol-1-yl)-N,N,N',N'-tetramethyluronium hexafluorophosphate
\end{tabular}

\section{Chemistry}

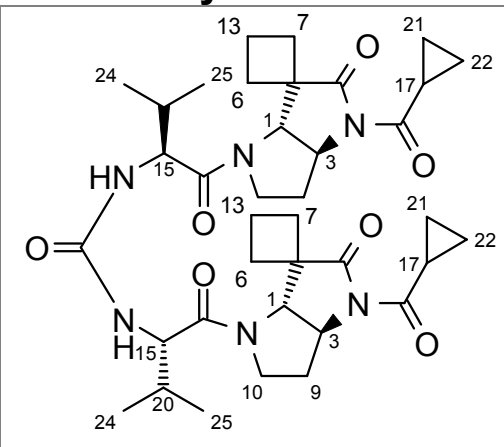

5
Synthesis of bis-valyl trans-lactam (5)

Amine hydrochloride (3a'R,6a'S)-1'-(2-methylpropanoyl)-4'-L-valylhexahydro$2^{\prime} H$-spiro[cyclobutane-1,3'-pyrrolo[3,2-b]pyrrol]-2'-one (3) ${ }^{1}$ (9 mg, $0.024 \mathrm{mmol}$ ), and diisopropylethylamine $(28 \mathrm{mg}, 0.22 \mathrm{mmol})$ in acetonitrile $(1 \mathrm{~mL})$ was treated with a solution of $p$-nitrophenyl chloroformate $(6 \mathrm{mg}, 0.03 \mathrm{mmol})$ in acetonitrile $(0.5 \mathrm{~mL})$ and the mixture stirred for one hour. A further portion of amine (3) $(10 \mathrm{mg}, 0.029 \mathrm{mmol})$ was added and the reaction stirred overnight at room temperature. The solvents were evaporated in vacuo and the residue was partitioned between ethyl acetate $(25 \mathrm{~mL})$ and sodium carbonate solution $(2 \mathrm{~N}, 25 \mathrm{~mL})$. The organic fraction was further washed with sodium carbonate solution ( $2 \mathrm{~N}, 25 \mathrm{~mL} \times 2$ ) and water $(25 \mathrm{~mL})$, dried over sodium sulfate and evaporated to yield a semi-solid which was purified by short silica column chromatography, eluting with cyclohexane:ethyl acetate (1:3). Fractions of interest were pooled and evaporated to yield $\mathbf{5}$ as a waxy cream solid $(11 \mathrm{mg}$, $61 \%$ Th.).

\footnotetext{
${ }^{1}$ Andrews, D.M.; Chaignot, H.; Coomber, BA.; Good, AC.; Hind, SL.; Johnson, MR.; Jones, PS.; Mills, G.; Robinson, JE.; Skarzynski, T.; Slater, MJ.; Somers, DO'N. Org. Lett. 2002, 4, 4479
} 


\begin{tabular}{|l|l|}
\hline & Mass spec $\mathrm{MH}^{+}$(found, electrospray +ve) 693 \\
& $\mathrm{MH}^{+}$(calculated for $\left.\mathrm{C}_{37} \mathrm{H}_{52} \mathrm{~N}_{6} \mathrm{O}_{7}+\mathrm{H}\right) 693$ \\
& ${ }^{1} \mathrm{H} N M R\left(\mathrm{~d}_{6} \mathrm{DMSO}\right) 6.41(\mathrm{~d}, 2 \mathrm{H}, \mathrm{NHCO}), 4.24(\mathrm{dd}, 2 \mathrm{H}, 15), 4.11-4.05(\mathrm{~m}, 2 \mathrm{H}$, \\
& $10), 3.81\left(\mathrm{ddd}, 2 \mathrm{H}, \mathrm{J}=10,10,6.5 \mathrm{~Hz}, 100^{\prime}\right), 3.39(\mathrm{ddd}, \mathrm{J}=11,11,4.5 \mathrm{~Hz}, 2 \mathrm{H}$, \\
& $3), 3.33(\mathrm{~d}, \mathrm{~J}=11 \mathrm{~Hz}, 2 \mathrm{H}, 1), 2.96-2.83(\mathrm{~m}, 4 \mathrm{H}, 17,7), 2.50-2.35\left(\mathrm{~m}, 4 \mathrm{H}, 9,7^{\prime}\right)$, \\
& $2.11-1.98(\mathrm{~m}, 8 \mathrm{H}, 6,13), 1.97-1.83\left(\mathrm{~m}, 2 \mathrm{H}, 20,9^{\prime}\right), 1.03-0.83(\mathrm{~m}, 20 \mathrm{H}, 21,22$, \\
& $24,25)$.
\end{tabular}
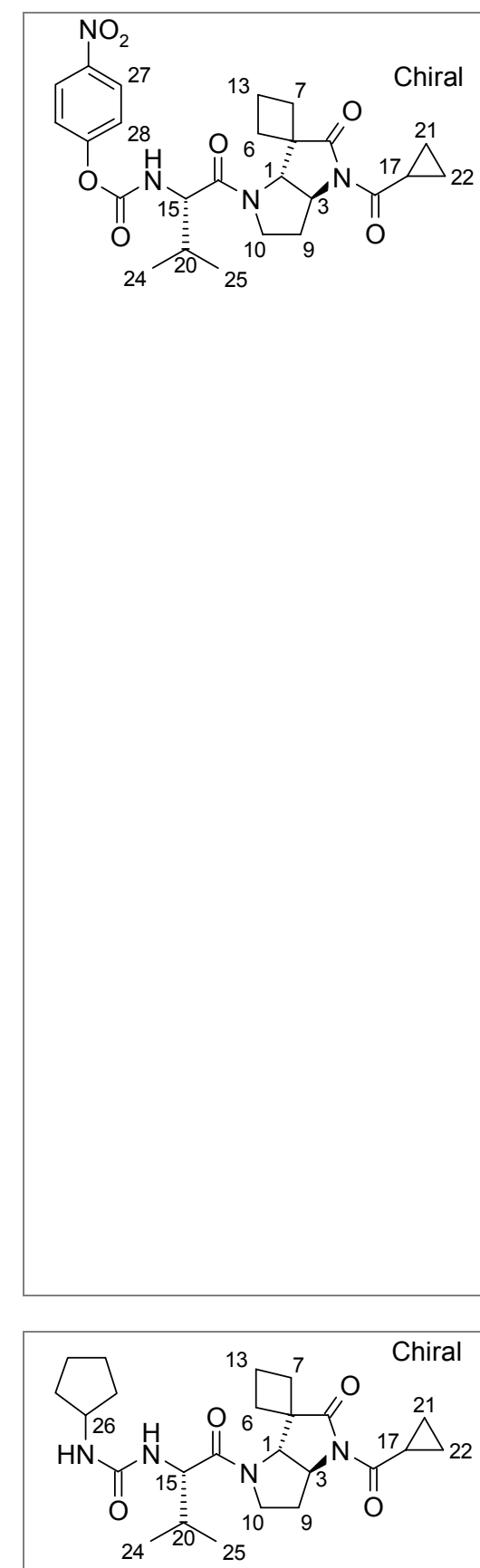

4-Nitrophenyl((1S)-1-\{[(3a'R,6a'S)-1'-(cyclopropylcarbonyl)-2'oxohexahydro-4'H-spiro[cyclobutane-1,3'-pyrrolo[3,2-b]pyrrol]-4'yl]carbonyl\}-2-methylpropyl)carbamate (6)

A solution of the amine (3) $(0.89 \mathrm{~g}, 2.7 \mathrm{mmol})$ in dry dichloromethane $(20 \mathrm{~mL})$ was added to a stirred solution of 4-nitrophenyl chloroformate $(0.706 \mathrm{~g}, 3.5$ $\mathrm{mmol})$ in dry dichloromethane $(20 \mathrm{~mL})$. The resulting colourless solution was treated with pyridine $(0.65 \mathrm{~mL}, 8.0 \mathrm{mmol})$, and the mixture was stirred at room temperature overnight. The reaction mixture was diluted with dichloromethane $(100 \mathrm{~mL})$ and washed successively with sodium carbonate solution $(0.5 \mathrm{M}, 25$ $\mathrm{mL}$ ) and $0.5 \mathrm{M}$-hydrochloric acid $(25 \mathrm{~mL})$. After drying over anhydrous sodium sulphate, the organic solution was evaporated to a cream foam $(1.45 \mathrm{~g})$. This foam was dissolved in dichloromethane $(40 \mathrm{~mL})$, and applied in equal portions to two silica $(20 \mathrm{~g})$ SPE cartridges. The cartridges were eluted with a gradient of ethyl acetate:petroleum ether $(1: 8,1: 4,1: 2$, then 1:1). The product containing fractions were combined and evaporated to give the $p$ nitrophenylcarbamate derivative (6) as a white solid (1.16 g, 86\% Th).

${ }^{1} \mathrm{H} \mathrm{NMR}\left(\mathrm{CDCl}_{3}\right) \delta 8.25(\mathrm{~d}, \mathrm{~J}=9 \mathrm{~Hz}, 2 \mathrm{H}, 27), 7.33(\mathrm{~d}, \mathrm{~J}=9 \mathrm{~Hz}, 2 \mathrm{H}, 28) 5.95(\mathrm{~d}$, $\mathrm{J}=9 \mathrm{~Hz}, N H), 4.42,4.17(\mathrm{dd}, \mathrm{J}=9,6 \mathrm{~Hz}, 1 \mathrm{H}, \mathrm{m}, 1 \mathrm{H}, 15,10), 3.89-3.81(\mathrm{~m}, 1 \mathrm{H}$, $10^{\prime}$ ), 3.42 (ddd, $\left.\mathrm{J}=11,10.5,5 \mathrm{~Hz}, 1 \mathrm{H}, 3\right), 3.32(\mathrm{~d}, \mathrm{~J}=11 \mathrm{~Hz}, 1 \mathrm{H}, 1), 3.04-2.92$ $(\mathrm{m}, 2 \mathrm{H}, 17,7), 2.81-2.73(\mathrm{~m}, 1 \mathrm{H}, 9), 2.66-2.57\left(\mathrm{~m}, 1 \mathrm{H}, 7^{\prime}\right), 2.21-1.93(\mathrm{~m}, 6 \mathrm{H}, 6$, 9', 13, 20), $1.11(\mathrm{~d}, 6.5 \mathrm{~Hz}, 3 \mathrm{H}, 24) 1.07(\mathrm{~d}, 6.5 \mathrm{~Hz}, 3 \mathrm{H}, 25) 1.21-0.95(\mathrm{~m}, 4 \mathrm{H}$, 21, 22).

Mass spec $\mathrm{MH}^{+}$(found, electrospray +ve) 499

$\mathrm{MH}+$ (calculated for $\mathrm{C}_{25} \mathrm{H}_{30} \mathrm{~N}_{4} \mathrm{O}_{7}+\mathrm{H}$ ) 499

N-Cyclopentyl-N'-((1S)-1-\{[(3a'R,6a'S)-1'-(cyclopropylcarbonyl)-2'oxohexahydro-4'H-spiro[cyclobutane-1,3'-pyrrolo[3,2-b]pyrrol]-4'yl]carbonyl\}-2-methylpropyl)urea (10g)

A solution of cyclopentylamine $(0.04 \mathrm{~mL}, 0.035 \mathrm{~g}, 0.4 \mathrm{mmol})$ and triethylamine $(0.17 \mathrm{ml}, 0.12 \mathrm{~g}, 1.2 \mathrm{mmol})$ in dichloromethane $(3 \mathrm{~mL})$ was added to a stirred solution of the p-nitrophenylcarbamate (6) $(0.1 \mathrm{~g}, 0.2 \mathrm{mmol})$ in dichloromethane $(3 \mathrm{~mL})$. The resulting yellow solution was stirred at room temperature. After $22 \mathrm{~h}$, the reaction mixture was washed successively with sodium carbonate solution $(0.5 \mathrm{M}, 4 \times 3 \mathrm{~mL})$ and hydrochloric acid $(0.5 \mathrm{M}, 3$ 


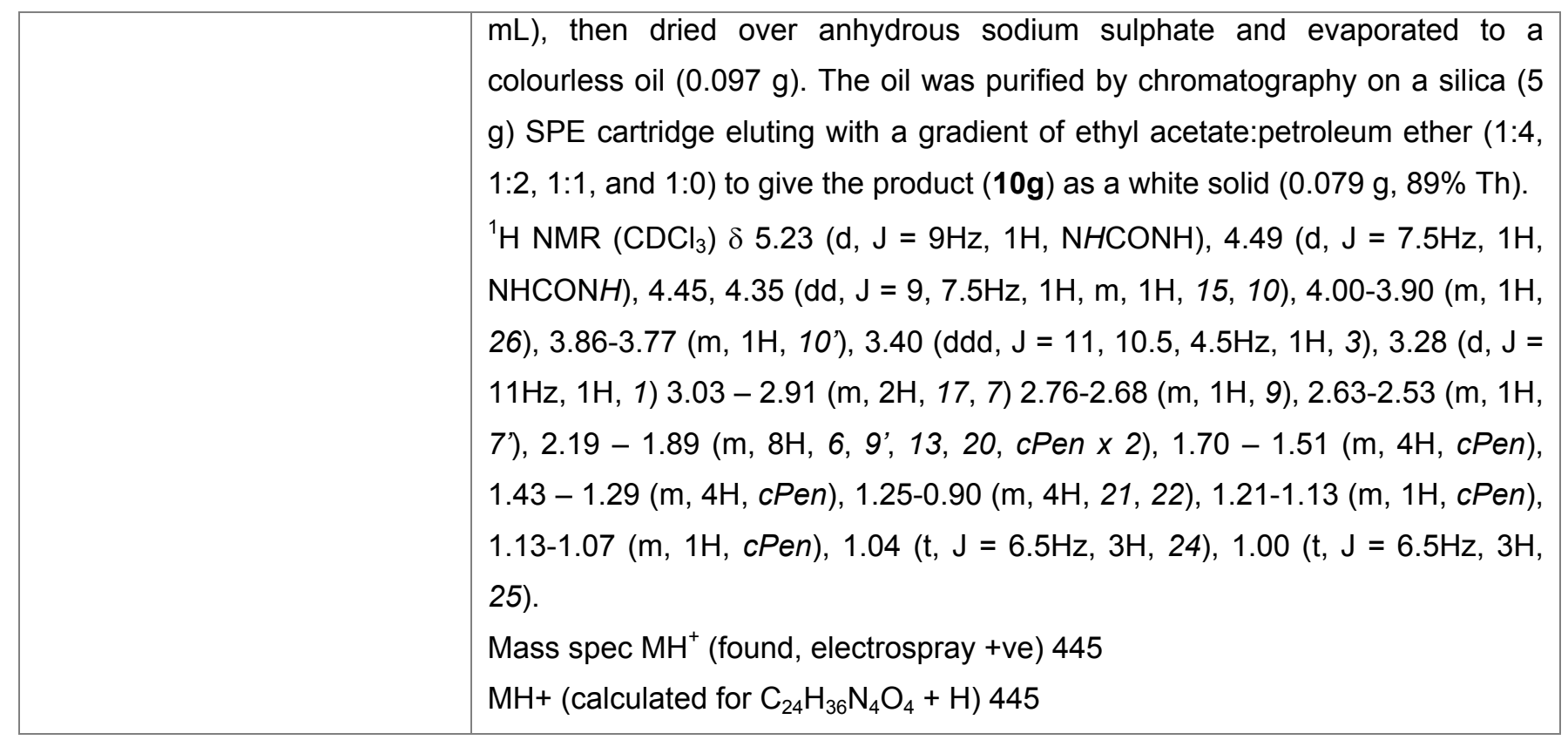

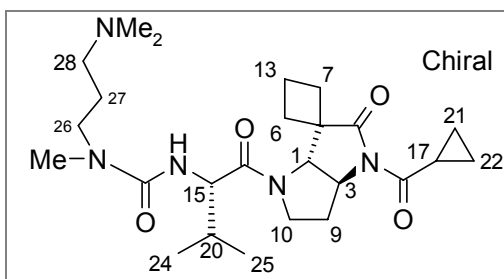

Array synthesis of $\mathrm{N}$-methyl-N-dimethylaminopropyl- $\mathrm{N}$-((1S)-2-methyl-1$\left\{\left[\left(3 a^{\prime} R, 6 a^{\prime} S\right)-1 '-(2-m e t h y l p r o p a n o y l)-2 '-o x o h e x a h y d r o-4 ' H-\right.\right.$ spiro[cyclobutane-1,3'-pyrrolo[3,2-b]pyrrol]-4'-yl]carbonyl\}propyl)urea (4a)

Amine hydrochloride (3a'R,6a'S)-1'-(2-methylpropanoyl)-4'-L-valylhexahydro-

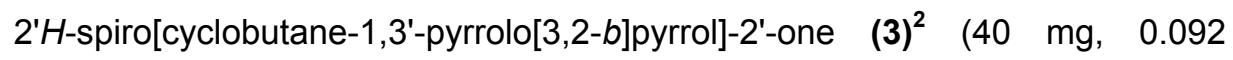
$\mathrm{mmol})$, was dissolved in dichloromethane $(2 \mathrm{~mL})$ and THF $(2 \mathrm{~mL})$ and diisopropylethylamine added ( $35 \mathrm{~mL}, 0.027 \mathrm{mmol}, 3$ equiv.). p-Nitrophenyl chloroformate (30 mg, $0.15 \mathrm{mmol}$ ) was added, the mixture stirred for one hour and split into two equal portions. To one portion was added 3-dimethylamino$\mathrm{N}$-methylpropylamine $(12 \mathrm{mg}, 0.1 \mathrm{mmol}$ ) The resulting solution was stirred at room temperature for 3 hours. The solvents were evaporated in vacuo and the residue was partitioned between ethyl acetate $(25 \mathrm{~mL})$ and sodium carbonate solution $(2 \mathrm{~N}, 25 \mathrm{~mL})$. The organic fraction was further washed with sodium carbonate solution ( $2 \mathrm{~N}, 25 \mathrm{~mL} \times 2)$ and water $(25 \mathrm{~mL})$, dried over sodium sulfate and evaporated to yield a gum. This was tested as the array sample. The purified sample was purified by short silica column chromatography, eluting with dichloromethane:ethanol:ammonia (100:8:1). Fractions of interest were pooled and evaporated to yield $\mathbf{4 a}$ as a colourless gum (13 $\mathrm{mg}, 61 \%$ Th.).

TLC: Rf 0.27 in dichloromethane:ethanol:ammonia (100:8:1).

${ }^{1} \mathrm{H}$ NMR $\left(\mathrm{CDCl}_{3}\right) 2$ rotamers apparent. $\delta 6.81$ and $6.55(2 \mathrm{br} \mathrm{s}, 1 \mathrm{H}, \mathrm{CONH})$, 4.5-4.4 (m, 0.5H, 10a), 4.27-4.14 (m, 1.5H, 15, 10a), 3.95-3.87 (m, 0.5H, 10b), 3.82-3.72 (m, 0.5H, 10b), 3.48-3.28 (m, 2H, 1, 3), 3.25-2.95 (m, 4H, 26, 28), 2.28 and $2.84(2 \mathrm{~s}, 3 \mathrm{H}, 25), 2.77-1.87\left(\mathrm{~m}, 10 \mathrm{H}, 17,7,6,13,20,9, N \mathrm{e}_{2}\right), 1.74-$

\footnotetext{
${ }^{2}$ Andrews, D.M.; et al. Org. Lett. 2002, 4, 4479.
} 


\section{Abridged Characterisation Data}

\section{Methods :}

NMR spectra $\left({ }^{1} \mathrm{H} 400 \mathrm{MHz},{ }^{13} \mathrm{C} 100 \mathrm{MHz}\right)$ were recorded on a Bruker DRX400, Bruker DPX400 or Varian Inova400 spectrometer. Chemical shifts $(\delta)$ are reported in ppm and coupling constants $(J)$ in $\mathrm{Hz}$. In $\mathrm{CDCl}_{3}$ chemical shifts were referenced using TMS as an internal standard or in $d_{6}$-DMSO using the residual solvent signal $\left[{ }^{1} \mathrm{H}: \delta=2.50 \mathrm{ppm},{ }^{13} \mathrm{C} \delta=39.5 \mathrm{ppm}\right]$. NMR Spectra were recorded at $27^{\circ} \mathrm{C}$ unless otherwise noted. HPLC analysis was achieved using a Hewlett Packard Series 1050 with a Phenomenex Prodigy 5 ODS-2 column (150 x 4.6mm). The mobile phase was $\mathrm{A}\left(\mathrm{H}_{2} \mathrm{O}+0.1 \%\right.$ TFA) and $\mathrm{B}(\mathrm{MeCN}+0.05 \% \mathrm{TFA})$ used as a linear gradient of 15 to $95 \%$ B over $14 \mathrm{~min}$ with a flow rate of $1.5 \mathrm{~mL} / \mathrm{min}$; detection was at $215 \mathrm{~nm}$. Elution times are quoted as $t_{R}$ in min. Values are +/- 0.2 min. Thermospray mass spectra were recorded on an HP5989B Engine, using aqueous ammonium acetate as solvent, with the filament in positive ion mode.

The following examples were prepared following the procedure described for $\mathbf{1 0 g}$.

\begin{tabular}{|c|c|c|c|}
\hline \multicolumn{4}{|c|}{ LC-MS Characterization } \\
\hline & $\begin{array}{l}\text { Molecular } \\
\text { Weight }\end{array}$ & $\begin{array}{l}\text { Electrospray } \\
\mathrm{MH}^{+} \text {found }\end{array}$ & $t_{R}(\min )$ \\
\hline $7 a$ & 532.69 & 533 & 3.67 \\
\hline $7 b$ & 566.70 & 567 & 3.72 \\
\hline $7 c$ & 490.60 & 491 & 3.12 \\
\hline $7 d$ & 462.59 & 463 & 3.07 \\
\hline $10 a$ & 376.46 & 377 & 2.30 \\
\hline $10 \mathrm{~b}$ & 404.51 & 405 & 2.76 \\
\hline $10 c$ & 418.54 & 419 & 3.04 \\
\hline $10 d$ & 416.52 & 417 & 3.05 \\
\hline $10 f$ & 430.55 & 431 & 3.06 \\
\hline $10 \mathrm{~h}$ & 458.61 & 459 & 3.27 \\
\hline $10 \mathrm{j}$ & 458.48 & 459 & 3.13 \\
\hline
\end{tabular}

\section{Biology}

\section{Chromogenic $\left(\mathrm{IC}_{50}\right)$ Assay}

The compound and the enzyme (200nM final concentration) were preincubated for 4 hours at $25^{\circ} \mathrm{C}$ followed by the addition of the substrate (Ac-EDVVPC-pNA, $1 \mathrm{mM}$ final concentration) to initiate the reaction. The rates were measured in a Biotek EL340 microplate reader measuring absorbance at $405 \mathrm{~nm}$. The data was exported to a results database (Activity Base) for curve fitting and/ $\mathrm{IC}_{50}$ inhibition determination. All compounds were dissolved in $100 \%$ DMSO at a concentration of $10 \mathrm{mM}$.

\section{Fluorogenic (Kobs/l) Assay}

This is a fluorescence resonance transfer assay using $\mathrm{Abz} / \mathrm{NO}_{2} \mathrm{Tyr}$ as the coupling agent. Upon cleavage of a peptide substrate (Aminobenzoyl-E-D-V-V-P-C-S-M-S-Y $\left(3-\mathrm{NO}_{2}\right)-\mathrm{NH}_{2}$ ) there is a signal increase at Em420nm (Ex320nm). 
NS3/4A full-length protease was made up to $25 \mathrm{nM}$ in buffer containing the following components: $62.5 \mathrm{mM}$ Hepes $\mathrm{pH} 8.0,0.0625 \%(\mathrm{v} / \mathrm{v}) \mathrm{NP}-40,0.375 \mathrm{M} \mathrm{NaCl}, 12.5 \%(\mathrm{v} / \mathrm{v})$ glycerol, $2.5 \mathrm{mM}$ DTT.

Compound dilutions were performed in 100\% DMSO. 3 concentrations (approximately 5 -fold apart) were chosen for each compound such that a Kobs/l value could be determined for each concentration. Appropriately diluted compound $(5 \mu \mathrm{l})$ was pipetted into a single well in a black 96 well flat-bottomed Microtiter plate.

The enzyme mixture, $75 \mu \mathrm{l}$ was added to each well. Substrate $(20 \mu \mathrm{l}, 25 \mu \mathrm{M}$ final concentration) was then immediately added to every well to initiate the reaction. The plate was placed in a FLUOstar reader (BMG LabTechnologies) and read for one hour at room temperature to collect progress plot data. The data was exported to GraFit 4 (Erithacus Software) to obtain a Kobs value for each compound concentration. The Kobs/l value was calculated by dividing the Kobs value by the molar concentration used. Units of measurement are $\mathrm{M}^{-}$ ${ }^{1} \mathrm{~s}^{-1}$

\section{Replicon ELISA}

\section{Cells}

The 5-15 subline of Huh-7 cells (Lohmann, V., Korner, F., Koch, J-O., Herian, U., Theilmann, L. \& Bartenschlager, R., 1999, Science, $\underline{285}$, pp110-113 ) were used for these assays. These are human hepatocellular carcinoma cells stably transfected with an HCV replicon comprising the majority of the HCV $1 \mathrm{~b}$ genome with the addition of a selectable marker gene, but lacking the genes encoding for all structural proteins and non-structural protein (NS) 2. The replicon RNA is self-replicating and fully functional viral proteins are translated from it. A quantifiable and specific reduction of expressed protein in the presence of a drug can be used as a measure of replicon inhibition.

\section{Compounds}

Stock solutions of compound samples were formulated to $40 \mathrm{mM}$ in DMSO.

\section{Assay Method}

Culture step: $100 \mu \mathrm{l}$ volumes of assay medium (Dulbecco's Minimal Essential Medium $\{\mathrm{DMEM}\}$ with 4500mg/L glucose and supplemented with $10 \%$ foetal bovine serum, $100 \mathrm{iu} / \mathrm{mL}$ penicillin, $100 \mu \mathrm{g} / \mathrm{mL}$ streptomycin, $2 \mathrm{mM} \mathrm{L-}$ glutamine and $1 \%$ non-essential amino acids solution) were added to each well of a 96-well tissue culture plate. The $40 \mathrm{mM}$ stock solutions of compound were further diluted in assay medium to twice the highest final concentration required, and $100 \mu \mathrm{l}$ aliquots were transferred into two wells in the top row of the plate. Serial doubling dilutions were then made down the plate leaving the bottom two rows compound free. A $100 \mu$ l volume of Huh-7 5-15 cell suspension of $2 \times 10^{5}$ cells $/ \mathrm{mL}$ in assay medium was added to all wells. The plates were incubated at $37^{\circ} \mathrm{C}$ in a $5 \% \mathrm{CO}_{2}$ atmosphere for 72 hours.

ELISA step: Growth medium was removed from the plate and the cell monolayers were washed gently once with phosphate buffered saline (PBS) prior to fixing with a 1:1 mix of acetone:methanol for 5 minutes. The plate was washed again with PBS, blotted dry and $100 \mu$ of ELISA diluent (PBS $+0.05 \%$ Tween $20+2 \%$ skimmed milk powder) was added to each well. The plate was incubated at $37^{\circ} \mathrm{C}$ for 30 minutes and the diluent removed. Each well, except one row of the compound free wells, then received $50 \mu$ l of murine monoclonal antibody, diluted to $1 \mu \mathrm{g} / \mathrm{mL}$, raised to a non-structural protein NS4a. The control row received 50 $\mathrm{\mu l} / \mathrm{well}$ of diluent alone. The plate was incubated for 2 hours, the primary antibody was removed and the cell sheets washed thoroughly with PBS + 
$0.05 \%$ Tween 20 . Rabbit anti-mouse, polyclonal antibody conjugated to horseradish peroxidase was diluted $1 / 1000$ and $50 \mu \mathrm{l}$ was added to all wells. Following incubation for one further hour, the secondary antibody was removed and the plate was washed thoroughly in PBS/Tween. The plate was blotted dry and 50 $\mu$ of orthophenylene diamine / peroxide substrate in urea buffer was added to all wells and colour development was allowed to proceed at room temperature. The reaction was stopped by the addition of $25 \mu$ per well of $2 \mathrm{M}$ sulphuric acid and the plates were read spectrophotometrically at $490 \mathrm{~nm}$.

The ELISA solutions were removed from the plates, and the cell sheets were washed with water, blotted dry and stained with $5 \%$ carbol fuchsin. After 30 minutes the stain was removed and the plates were washed with water and allowed to air dry.

\section{Data analysis}

The absorbence values from all compound-free wells that had received both primary and secondary antibodies were averaged to obtain a positive control value. The mean absorbence value from the compound-free wells that had not received the primary antibody was used to provide the negative (background) control value. The readings from the duplicate wells at each compound concentration were averaged and, after the subtraction of the mean background from all values, were expressed as a percentage of the positive control signal. Grafit software was used to plot the curve of percentage inhibition against compound concentration and derive the $50 \%$ inhibitory concentration $\left(\mathrm{IC}_{50}\right)$ for the compound.

In-assay cytotoxicity was assessed by microscopic examination of the stained cell sheets, and expressed as the lowest compound concentration at which any cytopathic effect was visible.

\section{Crystallography}

\section{Experiment:}

A $2.8 \AA \AA$ resolution X-ray structure of $10 \mathrm{~g}$ was obtained by soaking pre-formed crystals of NS3 protease domain/ synthetic $4 \mathrm{~A}$ co-factor ( $\mathrm{pH} 6.5$, compound concentration $2 \mathrm{mM}, 10 \%$ DMSO, 24hrs)

\section{Processing Statistics:}

Data processing was performed using the HKL data processing system ${ }^{2}$ and the processed data was analysed and scaled using the CCP4 programs suite. ${ }^{3}$

$\begin{array}{lcc} & \text { All data } & \text { (Outer shell [2.8-2.9A]) } \\ \text { Rmerge (40-2.8A) } & 0.08 & (0.439) \\ \text { No unique reflections } & 17371 & (1551) \\ \text { Data completeness }(\%) & 96.2 & (87.3)\end{array}$

Refinement Statistics: To be provided

PDB Deposition Code: To be provided

\footnotetext{
${ }^{2}$ Otwinowski,Z.; Minor, W. Methods Enzymol. 1997, 276, 307-325.

${ }^{3}$ Collaborative Computational Project, Number 4. Acta Cryst 1994, D50, 760-763. 